\title{
The Values Dimension of Quality Teachers: Can we prepare Pre-service Teachers for this?
}

\author{
By Elizabeth Curtis*
}

\begin{abstract}
The idea of teacher quality is at the forefront of educational debates and research globally. A teacher for the 21 st Century must be equipped with a sophisticated range of skills and capabilities, but it must go beyond knowledge, understanding and skills, to include effective dispositions, strong student/teacher relationships, communicative capacity, empathic character and self-awareness. Teacher quality encompasses many aspects, including skills, knowledge, attitudes, dispositions and values. This paper reports on a qualitative case study conducted with pre-service teachers in a Faculty of Education in an Australian university. One of the findings of the study points to the benefits of pre-service teachers engaging in an explicit values-based pedagogy. Through their engagement with such pedagogy, in this case Philosophy in the Classroom, the participants became more aware of the values dimension of quality teaching. If teachers are better prepared in the values dimension of teaching, this will make them more holistic quality teachers which will in turn positively impact upon student achievement and well-being.
\end{abstract}

Keywords: philosophy in the classroom; pre-service teacher education; Quality teaching; values education

\section{Introduction}

The latter part of the twentieth century and into the twenty-first century has seen a new learning paradigm emerge where research and practice into quality teaching, values education, and authentic pedagogy are united by the belief that learning is holistic (Lovat, Toomey, Clement, Crotty, \& Nielsen, 2009). This has resulted in a resurgence of educational literature surrounding quality teaching, with a "call for appropriate professional development to advance the quality of teaching in order to improve student achievement" (Clement, 2007, p. 22). Despite this plea though, little in-depth attention has been given to the development of quality teaching dimensions in pre-service teacher education. Whilst research exists to prove that there is a positive link between quality teaching and values education (see for example Lovat, 2007; Lovat \& Toomey, 2007b, 2007c; Lovat et al., 2009), this has not been investigated in any depth with regard to pre-service teacher education. It is hoped that the findings of this research may go some way in assisting the transparency of the relationship between values and quality teaching.

\section{Quality Teaching}

\footnotetext{
${ }^{*}$ Lecturer, Queensland University of Technology, Australia.
} 
A good teacher makes a difference, with it being argued that " there is no more important empirical determinant of student outcomes than good teaching" (Barber \& Mourshed, 2009, p. 27). Teacher excellence is an elusive concept and various definitions abound. Generally, much of the educational research literature surrounding the defining of 'expert' or 'quality' teachers has tended to focus on "technical, observable aspects of teaching" (Collinson, 1999). I would argue though that effective teachers are people who are competent across an array of domains including behaviour, cognition, content, character as well as knowledge of and sensitivity to cultural, social, political contexts and environments.

\section{Productive Pedagogy Model of Quality Teaching}

The Queensland School Reform Longitudinal Study (QSRLS) (The University of Queensland, 2001) produced a model of Productive Pedagogies (PP) to describe quality teaching. This model uses four dimensions: intellectual quality; connectedness; supportive classroom environment; and recognition of difference.

Intellectual Quality. The first of the PP dimensions is intellectual quality and it may be described in a variety of ways through a variety of criteria. 
Table 1. Intellectual Quality Criteria

\begin{tabular}{|c|c|}
\hline $\begin{array}{c}\text { Productive } \\
\text { pedagogy criteria }\end{array}$ & Explanation \\
\hline $\begin{array}{l}\text { Higher order } \\
\text { thinking }\end{array}$ & $\begin{array}{l}\text { This requires "students to manipulate information and } \\
\text { ideas in ways that transformed their meanings and } \\
\text { implications" (Hayes, Mills, Christie, \& Lingard, 2006, p. 42). }\end{array}$ \\
\hline Deep knowledge & $\begin{array}{l}\text { "Deep knowledge refers to the central ideas and concepts } \\
\text { of a particular topic and requires the students to display a } \\
\text { holistic understanding rather than a recitation of } \\
\text { fragmented information" (Curtis, 2012, p. 41). }\end{array}$ \\
\hline $\begin{array}{l}\text { Knowledge as } \\
\text { problematic }\end{array}$ & $\begin{array}{l}\text { This is where an ability to comprehend that knowledge is } \\
\text { not fixed but is subjective is vital. }\end{array}$ \\
\hline $\begin{array}{l}\text { Substantive } \\
\text { conversation }\end{array}$ & $\begin{array}{l}\text { Refers to considerable teacher-student and student-student } \\
\text { exchanges which must play a central role in the } \\
\text { classroom. Group interactions are an important aspect of } \\
\text { effective learning with a strong association found between } \\
\text { student achievement and group interactions, especially } \\
\text { when the interactions involved giving a high-level of } \\
\text { explanation and/or elaboration (Webb, } 1989 \text { as cited in } \\
\text { Topping \& Trickey, 2007). }\end{array}$ \\
\hline Metalanguage & $\begin{array}{l}\text { Refers to teaching with high levels of talk and discussion } \\
\text { regarding talk, writing, specific technical vocabulary, } \\
\text { syntax, grammar, semantics, and genre. Teachers who } \\
\text { effectively use metalanguage have been found to pull back } \\
\text { from activities and foreground such elements as words, } \\
\text { sentences, text features, and discourses (Hayes et al., } \\
\text { 2006). }\end{array}$ \\
\hline $\begin{array}{l}\text { Critical and } \\
\text { creative thinking }\end{array}$ & $\begin{array}{l}\text { Critical thinking contains the ability to think effectively } \\
\text { and fair-mindedly regarding one's own beliefs as well as } \\
\text { those which are diametrically opposed, and not just to } \\
\text { think about them but to explore and appreciate them, and } \\
\text { it involves skills, attitudes and passions - it permeates } \\
\text { one's life (Paul, 1993). Creative thinking can be seen to be } \\
\text { built upon the concepts of wondering, questioning, } \\
\text { speculating and inventing(Davey Chesters, 2012). It was } \\
\text { Matthew Lipman, educationalist and philosopher, who } \\
\text { whilst basing his work on Dewey's notion of reflective } \\
\text { thinking, developed an argument that excellent thinking is } \\
\text { critical, creative and complex (Lipman, 2003). "Children } \\
\text { who think for themselves are both critical and creative } \\
\text { thinkers. They value logical and conceptual thinking, but } \\
\text { they also enjoy speculating, imagining, inventing, } \\
\text { discovering and wondering" (Splitter \& Sharp, 1995, p. 97). }\end{array}$ \\
\hline
\end{tabular}

A supportive classroom environment. The next dimension within the PP framework is a supportive classroom environment. The data collected from the QSRLS demonstrated that teachers scored most highly on supportive classroom environment out of the four dimensions (The University of Queensland, 2001), as well as most often identifying this dimension as an 
important aspect of a good classroom (Hayes et al., 2006).

\section{Table 2. A Supportive Classroom Environment Criteria}

\begin{tabular}{|c|l|}
\hline $\begin{array}{c}\text { Productive } \\
\text { pedagogy criteria }\end{array}$ & \multicolumn{1}{|c|}{ Explanation } \\
\hline $\begin{array}{c}\text { Academic } \\
\text { engagement }\end{array}$ & $\begin{array}{l}\text { This can be identified by on-task behaviours that } \\
\text { demonstrate attentiveness, engaging with the assigned } \\
\text { task, showing initiative by raising questions, contributing } \\
\text { to group work and assisting peers (Hayes et al., 2006). }\end{array}$ \\
\hline Self-regulation & $\begin{array}{l}\text { In a classroom where students display self-regulated } \\
\text { behaviour there will be a noticeable lack of teacher } \\
\text { behaviour management intervention. }\end{array}$ \\
\hline Student direction of & $\begin{array}{l}\text { Students have a direct influence on the tasks undertaken in } \\
\text { the classroom, and these tasks are more likely to be } \\
\text { atudent-centred and involve research/investigative } \\
\text { activities. }\end{array}$ \\
\hline Social support & $\begin{array}{l}\text { The teacher demands high expectations of all students } \\
\text { thus creating an environment where it is safe to take } \\
\text { intellectual risks and where all members of the class have } \\
\text { mutual respect for each other. }\end{array}$ \\
\hline Explicit criteria & $\begin{array}{l}\text { This criterion has strong links to assessment. The criteria } \\
\text { should make expectations explicit and this must clearly } \\
\text { relate to what constitutes high quality performance and } \\
\text { not simply completed work (The University of } \\
\text { Queensland, 2001). It also has links to social justice issues } \\
\text { where it is important that teachers moderate across year } \\
\text { levels within a school and also with other schools in the } \\
\text { area. }\end{array}$ \\
\hline
\end{tabular}

Connectedness. This dimension of the PP research considers the extent to which classrooms are connected to the world beyond its walls and the criteria demonstrates connections between bodies of knowledge and with the world beyond the classroom and school.

Table 3. Connectedness Criteria

\begin{tabular}{|c|c|}
\hline $\begin{array}{c}\text { Productive } \\
\text { pedagogy criteria }\end{array}$ & Explanation \\
\hline $\begin{array}{l}\text { Knowledge } \\
\text { integration }\end{array}$ & $\begin{array}{l}\text { This is when a teacher explicitly connects two or more sets of } \\
\text { subject area knowledge, or where a holistic curriculum is } \\
\text { evident and there are no subject boundaries that are readily } \\
\text { identifiable. }\end{array}$ \\
\hline $\begin{array}{l}\text { Background } \\
\text { knowledge }\end{array}$ & $\begin{array}{l}\text { Within this element considerations and connections are made to } \\
\text { such things as students' personal experiences, popular culture, } \\
\text { media, community knowledge, and cultural knowledge. }\end{array}$ \\
\hline $\begin{array}{l}\text { Connectedness to the } \\
\text { world }\end{array}$ & $\begin{array}{l}\text { This relates to the extent to which a class demonstrates "value } \\
\text { and meaning beyond the pedagogical context" (Hayes et al., } \\
2006 \text {, p. 55) by working on real-world problems as well as } \\
\text { utilising their personal experiences. }\end{array}$ \\
\hline $\begin{array}{l}\text { Problem-based } \\
\text { curriculum }\end{array}$ & $\begin{array}{l}\text { A teacher needs to present the class with problems that have no } \\
\text { specified correct solution, thus requiring students to develop } \\
\text { knowledge construction over a series of lessons. }\end{array}$ \\
\hline
\end{tabular}


Recognition of difference. This dimension of working with and valuing difference is seen as being crucial in order to effectively develop academic and social outcomes of all students, including marginalised ones (Hayes et al., 2006). It is in this final dimension that active citizenship and thoughts about a future society are considered.

Table 4. Recognition of Difference Criteria

\begin{tabular}{|c|c|}
\hline $\begin{array}{c}\text { Productive } \\
\text { pedagogy criteria }\end{array}$ & Explanation \\
\hline Cultural knowledge & $\begin{array}{l}\text { A classroom that has effective cultural knowledge will value all } \\
\text { cultures and will ensure that more than one culture is present } \\
\text { and valued. By ensuring this element exists within a classroom, } \\
\text { students should recognise, include and transmit different } \\
\text { cultural knowledge (Curtis, 2012). }\end{array}$ \\
\hline Inclusivity & $\begin{array}{l}\text { This refers to the degree which non-dominant groups are } \\
\text { represented in classroom practices. A critical aspect of } \\
\text { education is working with and valuing difference (Hayes et al., } \\
\text { 2006; Landorf, Rocco, \& Nevin, 2007). }\end{array}$ \\
\hline Narrative & $\begin{array}{l}\text { Narrative is marked by an emphasis in teaching and in student } \\
\text { responses using genres such as personal stories, biographies, } \\
\text { historical accounts and literary and cultural texts. }\end{array}$ \\
\hline $\begin{array}{l}\text { Group identities in a } \\
\text { learning community }\end{array}$ & $\begin{array}{l}\text { There is an emphasis on the creation of "learning communities } \\
\text { in which difference and group identities are positively } \\
\text { recognised and developed within a collaborative and supportive } \\
\text { classroom community (Hayes et al., 2006, p. 69). If this is to be } \\
\text { effectively achieved it needs to extend beyond a simple } \\
\text { tolerance to a positive and legitimate understanding and valuing } \\
\text { of multiple identities and cultures (Curtis, 2012). }\end{array}$ \\
\hline Active citizenship & $\begin{array}{l}\text { This can be seen in a classroom context where the teacher } \\
\text { elaborates on the meaning of citizenship and facilitates it in a } \\
\text { practical sense both within and without the classroom. Global } \\
\text { education provides a wonderful opportunity for students to } \\
\text { engage in active citizenship, as too does service learning where } \\
\text { links are made between moral, intellectual and civic life, the } \\
\text { academic course, and service learning objectives with real } \\
\text { community needs (Landorf et al., 2007) }\end{array}$ \\
\hline
\end{tabular}

\section{Quality Teaching and Values Education}

Research has demonstrated that there is a correlation between values education and improved academic achievement for students (Benninga, Berkowitz, Kuehn, \& Smith, 2006) as well as the development of personhood (Davidson, Khmelkov, \& Lickona, 2010). There have also been studies conducted on the relationship between quality teaching and values education and the impact this has on student achievement and wellbeing (see for example: Lovat \& Clement, 2008; Lovat, Dally, Clement, \& Toomey, 2011; Osterman, 2010; Sokol, Hammond, \& Berkowitz, 2010).

In Australia, Lovat, Toomey, and Clement (Clement, 2007; Lovat, 2007; Lovat \& Clement, 2008; Lovat \& Toomey, 2007a, 2007b; Toomey, 2006, 2007) have written extensively on the link between values education and 
quality teaching. Values in education has been noted to have a power beyond a narrow definition in terms of morality and citizenship - it is "seen to be at the centre of all that a committed teacher and school could hope to achieve through teaching." (Lovat \& Toomey, 2007b, p. xiv). Thus values education has been identified as the missing link in quality teaching (Lovat \& Toomey, 2007b).

This link between values and quality teaching has also been noted by Carr (2007) who argues that many teaching and classroom problems are not always a result of failures to implement effective teaching pedagogies but rather factors that have more to do with attitudes and motivation. So if society wants better education for its youth, then it must look to pre-service teacher education. It is in these programmes that we must ensure that quality teaching and values education are explicitly modelled, taught and practised.

Thus in this study a fifth dimension to the already four dimensions of the Productive Pedagogy model has been added to complete a quality teaching model..

Table 5. Values Criteria

\begin{tabular}{|c|l|}
\hline Criteria & \multicolumn{1}{|c|}{ Explanation } \\
\hline $\begin{array}{c}\text { Teachers' values, } \\
\text { beliefs and attitudes }\end{array}$ & $\begin{array}{l}\text { It is important for teachers to be able to clearly articulate } \\
\text { their beliefs so that the process of understanding their } \\
\text { beliefs and how this will impact upon their instructional } \\
\text { decisions and practices (Collinson, 1996) is able to } \\
\text { develop. Self-understanding and awareness of these } \\
\text { values, attitudes and beliefs is vital. }\end{array}$ \\
\hline Teacher & $\begin{array}{l}\text { Teacher dispositions in the literature are also referred to } \\
\text { by the terms, 'temperament', 'traits' and 'habits'(Dottin, } \\
\text { 2009). These dispositions can include open-mindedness } \\
\text { (Collinson, 1996); care (Goldstein \& Lake, 2000; } \\
\text { Noddings, 2001, 2005); a passion for learning (Eisner, } \\
\text { 2006); virtue (Osguthorpe, 2008) and the desire to make a } \\
\text { difference (Eisner, 2006). }\end{array}$ \\
\hline $\begin{array}{c}\text { This relationship building implies agency, efficacy, } \\
\text { respect by the teacher for what the child brings to the class } \\
\text { and allowing the experiences of each individual child to } \\
\text { be recognised and valued within the classroom (Hattie, } \\
\text { 2009). Research has demonstrated that the quality of the } \\
\text { reacher-child relationship may either facilitate or inhibit a } \\
\text { child's successful adjustment to school; as well as either } \\
\text { promoting or hindering learning (Birch \& Ladd, 1996; } \\
\text { Pianta \& Stuhlman, 2004). }\end{array}$ \\
\hline
\end{tabular}

Thus the model of quality teaching that was used in this study looks like this. 
Figure 1. Quality Teaching Model

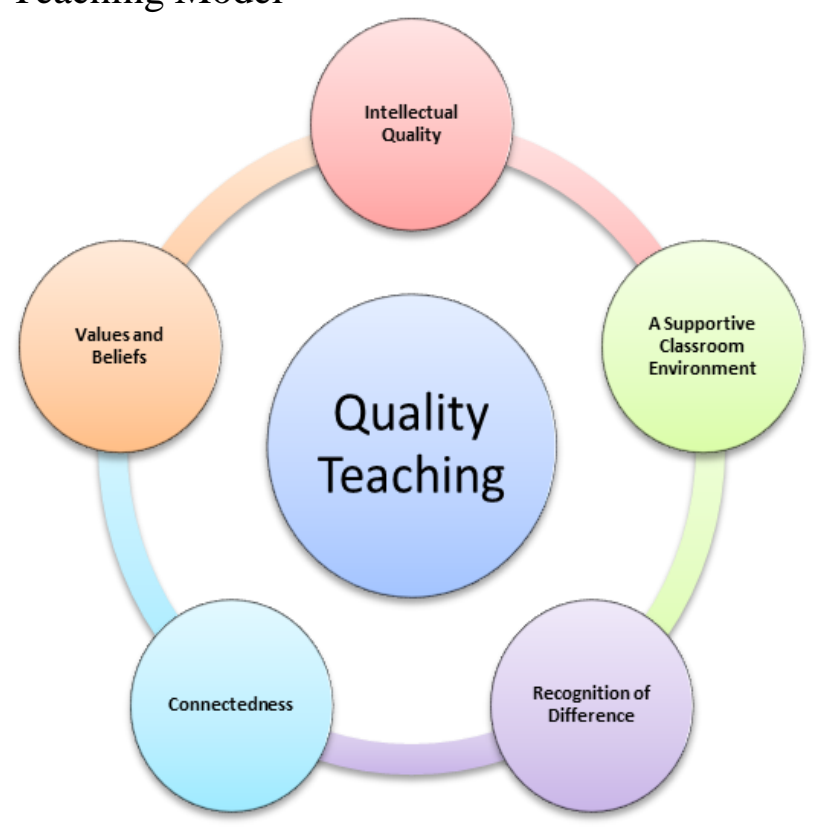

\section{Values Education}

There are different terms used for values education in the literature, for example moral education, character education, personal and social education, citizenship education or civic education. In this study, values education is defined as an awareness of the moral, social, political and aesthetic things humans believe in and intrinsic to this is the development of autonomous and life-long learners. It is perceived that one of the main aims of values education is to provide students with a knowledge of themselves and a mode of relating to others. Values education is not promoting the use of pedagogical strategies whose aim it is to indoctrinate. The goal is to "both 'educate the emotions' and to 'affect the intellect'. (Tan \& Leong, 2006).

The research that this paper is presenting views values education as an holistic pedagogy which impacts on the entire school curriculum and the way teachers teach." By viewing values education in this light, as opposed to seeing it as a discrete subject or unit, means all teachers need to be provided with knowledge and skills in values education" (Curtis, 2012, p. 8). This research programme describes one way that an explicit values-based pedagogy in pre-service teacher education can become a more prominent feature of preservice teacher education. In doing so, it provides opportunities for beginning teachers to engage with values as part of their professional learning and in so doing contributes to better understanding and growth in quality teaching dimensions. In researching how a values-based pedagogy in pre-service teacher programmes can assist with quality teaching, this research may encourage teacher education institutions and teacher educators to more seriously consider 
the role of values in pre-service teacher education and the important contributions it can make to producing better quality teachers.

\section{Philosophy in the Classroom}

The explicit values-based pedagogy that was utilised in this study was Philosophy in the Classroom. The use of Philosophy in the Classroom to enhance children's thinking skills was revived in the US by Matthew Lipman at the beginning of the 1970s with his Philosophy for Children (P4C) approach (Daniel \& Auriac, 2009). The aim of this programme was to teach children how to think for themselves and make informed choices (Lipman, 2003; Lipman, Sharp, \& Oscanyan, 1980). It has been seen to increase and strengthen knowledge and understanding; to improve critical and creative thinking; to build community; to assist with personal and emotional development and; to improve language skills (Curtis, 2012). Through Philosophy in the Classroom, as one example of a values-based pedagogy, children can learn how to reason, how to critically think, how to deal with diverse peoples and ideas, and cultivate good social habits that will enhance their moral, social and intellectual conduct (Curtis, 2012). Philosophy in the Classroom is not simply a skills programme but is an approach to teaching and learning where philosophical thinking is enhanced (Davey Chesters, 2012).

\section{Purpose of the Study}

The two principal research questions addressed were:

1. In what ways do pre-service teachers perceive they are being prepared to become quality teachers?

2. Is there a connection between an explicit values-based pedagogy in pre-service teacher education and the development of pre-service teachers' understanding of quality teaching?

This paper is only commenting on the findings associated with research question two. Research question one will be reported on in a separate paper.

\section{Method}

The particular values-based pedagogy that was used in this research was that of Philosophy in the Classroom. Quality teaching was defined in this research programme by five dimensions: the four PP dimensions of intellectual quality; a supportive classroom environment; recognition of difference and; connectedness; as well as a fifth dimension of values. 


\section{Context and Participants}

The research was reported in a nested case study design which involved three studies. Study One provided insight into 21 primary pre-service teachers' understandings of quality teaching. No participant in Study One had engaged in the values explicit pedagogy as participants in Studies Two and Three had. Study Two involved the interviewing of 22 primary pre-service teachers at two separate points of time (before exposure to the values-based pedagogy of philosophy in the classroom and after). Study Three analysed five participants of Study Two and involved interviewing the five participants a third time after their field experience.

All participants in all three studies were enrolled in the four year Bachelor of Education (Primary) programme at the same university, which was a large university in South-East Queensland that has a large Faculty of Education and has a long history of teacher education.

\section{Data Sources}

The study employed a qualitative methodology with interviews as the source of data collection. The interviews provided rich contextual data on preservice teachers' understandings of quality teaching and the roles played by a values explicit pedagogy on these understandings.

\section{Findings and Discussion}

The findings are discussed under the headings of the quality teaching model (see Figure 1). To demonstrate the extent of the connection between a values explicit focus and a non-values explicit focus each dimension is first discussed by displaying a table clearly showing a comparison between the nonvalues explicit and the values explicit. 


\section{Intellectual Quality}

Table 6. Comparison of Participants' Understandings of the Intellectual Quality Dimension between Non-Values Explicit and Values Explicit

\begin{tabular}{|c|c|c|}
\hline $\begin{array}{c}\text { Study One } \\
\text { Non Values Explicit } \\
\text { Pedagogy }\end{array}$ & $\begin{array}{c}\text { Study Two } \\
\text { Values Explicit Pedagogy } \\
\text { Subject }\end{array}$ & $\begin{array}{c}\text { Study Three } \\
\text { Values Explicit Pedagogy } \\
\text { Subject + Post Field } \\
\text { Experience }\end{array}$ \\
\hline $\begin{array}{c}\text { Teaching strategies such } \\
\text { as Bloom's Taxonomy, } \\
\text { Gardner's multiple } \\
\text { intelligences }\end{array}$ & $\begin{array}{c}\text { Higher-order thinking } \\
\text { Deep knowledge and deep } \\
\text { understanding }\end{array}$ & $\begin{array}{c}\text { All students have an } \\
\text { opportunity in philosophy } \\
\text { despite academic results } \\
\text { Development of substantive } \\
\text { Critical and creative } \\
\text { chinking in terms of deep } \\
\text { understanding and } \\
\text { construction of own } \\
\text { knowledge }\end{array}$ \\
$\begin{array}{c}\text { Connecting to real life and } \\
\text { outside the classroom } \\
\text { Cross-curricular teaching } \\
\text { Philosophy reduces teacher } \\
\text { talk }\end{array}$ & $\begin{array}{c}\text { Deep level of students } \\
\text { responses came as a surprise } \\
\text { Higher-order thinking }\end{array}$ \\
Connecting to different & & \\
perspectives, real life & & \\
and outside the & & \\
classroom & & \\
\hline
\end{tabular}

Source: Curtis, 2012, p. 238

Exposure to the values-based pedagogy of Philosophy in the Classroom enhanced the pre-service teachers' understandings of the quality teaching dimension of intellectual quality. Without the values-based pedagogy the participants stressed the importance of particular teaching strategies to increase students' higher-order thinking but didn't necessarily always know how to use these effectively:

We're pushed to create, like we're encouraged to create lesson plans that promote higher-order thinking, but in reality you get into the classroom....and the kids don't want higher-order thinking they just want their knowledge so they can pass (Study One Participant 7).

Philosophy in the Classroom with its focus on a community of inquiry and student direction aided the pre-service teachers in gaining skills in allowing for elements of uncertainty and unpredictability in instructional and outcome processes.

I think particularly with the fact that the kids are looking at a set concept and kind of something that they may think is very right or wrong and then say, 'oh! Well we're going to blur the lines. What if it's in this circumstance?' Get them to think...That kind of would link in with the knowledge not as a fixed body of information...Developing their justification skills and things so that they're reasoning within themselves and that's kind of questioning how they view the world as well (Study Two Participant 9). 
The exposure to the values-based pedagogy and the opportunity to implement this for themselves whilst on field experience allowed the participants to see much greater levels of higher order intellectual quality in children than they had previously considered possible. " You could see like sort of a light starting to shine and...the odd kid say something really deep and philosophical...the potential's there" (Study Three - Clara). It is well documented in the research literature (see for example Cam, 1995; Cam, 2006; Daniel \& Auriac, 2009; Lipman et al., 1980; McCall, 2009) that the practice of engaging in regular philosophical communities of inquiry aids in the development of critical, complex and creative thinking (Lipman, 2003) where learning is focused on the active construction of knowledge rather than reproduction (Hayes et al., 2006).

\section{A Supportive Classroom Environment}

Table 7. Comparison of Participants' Understandings of the Supportive Classroom Environment Dimension between Non-Values Explicit and Values Explicit

\begin{tabular}{|c|c|c|}
\hline $\begin{array}{c}\text { Study One } \\
\text { Non Values Explicit } \\
\text { Pedagogy }\end{array}$ & $\begin{array}{c}\text { Study Two } \\
\text { Values Explicit Pedagogy } \\
\text { Subject }\end{array}$ & $\begin{array}{c}\text { Study Three } \\
\text { Values Explicit Pedagogy } \\
\text { Subject + Post Field } \\
\text { Experience }\end{array}$ \\
\hline & Relationships - & Relationships in \\
philosophy reduces & classroom improved \\
bullying & Students who didn't \\
Relationships & The development of & normally participate, did \\
Valuing of student work & student self-esteem where & so in philosophy \\
and diversity & they begin to value their & Students learnt to respect \\
Rules/behaviour & own opinions & others' opinions \\
management & Rules/behaviour & Behavioural problems \\
& management & decreased - helped with \\
& Student self-regulation & teacher behaviour \\
& & management \\
\hline
\end{tabular}

Source: Curtis, 2012, p. 240

Both the non-values explicit and values explicit groups identified the importance of effective relationships and social support within a classroom, however it seemed that the pre-service teachers with the values explicit pedagogy were more confident in knowing exactly how to ensure this occurred effectively. Research has demonstrated that establishing secure, caring relationships are vital for learning and the commitment of students to work together as well as being crucial to the development of an environment that is supportive of ethical behaviour (Narvaez, 2010). While the importance of establishing secure caring relationships was recognised by all participants, it was those pre-service teachers who had engaged with the Philosophy in the Classroom pedagogy who could see the potential for moral development: 
They were getting really good at doing the whole I love what you had to say, or I like the idea. They learnt very quickly that you don't disagree with the person you disagree with the idea and they were telling their friends about that at lunch and that's not how we talk. So I can see how that would filter out into the playground and stuff like that (Study Three - Clara).

Increased student self-esteem was also noted by the participants in the values explicit subject, which is significant in demonstrating that a supportive classroom environment is enhanced through the use of a values explicit pedagogy. Student self-confidence in their own opinions and their articulation of these in a shared community of inquiry strongly suggests that they feel safe and valued by all class members.

\section{Recognition of Difference}

Table 8. Comparison of Participants' Understandings of the Recognition of Difference Dimension between Non-Values Explicit and Values Explicit

\begin{tabular}{|c|c|c|}
\hline $\begin{array}{c}\text { Study One } \\
\text { Non Values Explicit } \\
\text { Pedagogy }\end{array}$ & $\begin{array}{c}\text { Study Two } \\
\text { Values Explicit Pedagogy } \\
\text { Subject }\end{array}$ & $\begin{array}{c}\text { Study Three } \\
\text { Values Explicit Pedagogy } \\
\text { Subject + Post Field } \\
\text { Experience }\end{array}$ \\
\hline $\begin{array}{c}\text { Inclusivity in terms of } \\
\text { different learning styles, } \\
\text { needs, abilities, and } \\
\text { cultures }\end{array}$ & $\begin{array}{c}\text { needs, abilities and cultures } \\
\text { Talk about difference } \\
\text { without judgment being } \\
\text { passed }\end{array}$ & $\begin{array}{c}\text { Students appeared to better } \\
\text { understand difference in } \\
\text { their own classroom } \\
\text { context after philosophy } \\
\text { lessons }\end{array}$ \\
\hline
\end{tabular}

Source : Curtis, 2012, p. 242

The importance of the valuing of cultural knowledge and adopting a global perspective was noted by all participants regardless of a values explicit pedagogy or not. This finding was not surprising given that diversity and inclusivity have been leading agendas within education and teacher education programmes since the latter part of the $20^{\text {th }}$ century (Cochran-Smith \& Fries, 2008; Keeffe, 2007; Slee, 2007; UNESCO, 1994). What was observed by participants in the values-based subject though was how the pedagogy of Philosophy in the Classroom provided them with an explicit way of incorporating substantive conversation with specific regard to inclusivity and cultural knowledge. This was done both through the shared narrative, which became the stimulus for the philosophy lesson/s, and the actual discussion in the community of inquiry itself. 


\section{Connectedness}

Table 9. Comparison of Participants' Understandings of the Connectedness Dimension between Non-Values Explicit and Values Explicit

\begin{tabular}{|c|c|c|}
\hline $\begin{array}{c}\text { Study One } \\
\text { Non Values Explicit } \\
\text { Pedagogy }\end{array}$ & $\begin{array}{c}\text { Study Two } \\
\text { Values Explicit Pedagogy } \\
\text { Subject }\end{array}$ & $\begin{array}{c}\text { Study Three } \\
\text { Values Explicit Pedagogy } \\
\text { Subject + Post Field Experience }\end{array}$ \\
\hline $\begin{array}{l}\text { To something bigger (real } \\
\text { life and world beyond } \\
\text { classroom) } \\
\text { Making it relevant by } \\
\text { connecting to real world } \\
\text { problems and issues } \\
\text { In a local sense to school } \\
\text { and community } \\
\text { In terms of diversity }\end{array}$ & $\begin{array}{l}\text { To something bigger (real } \\
\text { life and world beyond } \\
\text { classroom) } \\
\text { Connections made to } \\
\text { students' own lives } \\
\text { Making it relevant by } \\
\text { connecting to real world } \\
\text { problems and issues } \\
\text { Life-long learning skills } \\
\text { In terms of diversity } \\
\text { Cross-curricular }\end{array}$ & $\begin{array}{l}\text { Students didn't always make } \\
\text { connections between issues in } \\
\text { philosophy and their own lives } \\
\text { Life-long learning skills } \\
\text { Made better connections with } \\
\text { others in the class } \\
\text { Cross-curricular }\end{array}$ \\
\hline
\end{tabular}

Source: Curtis, 2012, p. 243

Knowledge integration was not mentioned by the non-values explicit participants; however, after being exposed to the value-explicit pedagogy the pre-service teachers immediately became aware of the potential of Philosophy in the Classroom in connecting and integrating knowledge across all areas of the curriculum. Whilst ideally Philosophy in the Classroom should be a way of assisting students to make strong connections between their own lives and big issues within society (Lipman et al., 1980), this is not always the case as observed by one participant when students clearly demonstrated examples of stealing in the philosophy lesson but then did not make links to what was occurring in their own classroom regarding the issue of stealing. Regardless of whether the students made links in this instance or not, what is important is the finding that a values-based pedagogy such as Philosophy in the Classroom does provide students with a means of making strong connections between different subjects and content areas; to others both within and without the classroom; to the world beyond the classroom; and to their own and others' experiences (Curtis, 2012).

Life-long learning skills was an element of connectedness only mentioned by those participants who were engaged in the values-explicit subject with clear links being made between philosophy in the classroom and its skills of open-mindedness; reflective thinking; self-regulation; self-knowledge; and critical and creative thinking, all of which are crucial dispositions for life-long learning (Curtis, 2010). 


\section{Values}

Table 10. Comparison of Participants' Understandings in the Values Dimension between Non-Values Explicit and Values Explicit

\begin{tabular}{|c|c|c|}
\hline $\begin{array}{c}\text { Study One } \\
\text { Non Values Explicit } \\
\text { Pedagogy }\end{array}$ & $\begin{array}{c}\text { Study Two } \\
\text { Values Explicit Pedagogy } \\
\text { Subject }\end{array}$ & $\begin{array}{c}\text { Study Three } \\
\text { Values Explicit Pedagogy } \\
\text { Subject + Post Field } \\
\text { Experience }\end{array}$ \\
\hline $\begin{array}{c}\text { Teacher dispositions such } \\
\text { as a positive attitude, self- } \\
\text { knowledge and impact on } \\
\text { students } \\
\text { Teachers as role models } \\
\text { The importance of } \\
\text { building positive } \\
\text { relationships }\end{array}$ & $\begin{array}{c}\text { Self-knowledge } \\
\text { Strengthened teachers' } \\
\text { values and beliefs } \\
\text { Teachers as role models } \\
\text { Building positive } \\
\text { relationship } \\
\text { Pedagogy useful for } \\
\text { discussing school and } \\
\text { social issues of concern } \\
\text { Increased respect }\end{array}$ & $\begin{array}{l}\text { Pedagogy useful for } \\
\text { discussing school and } \\
\text { social issues of concern }\end{array}$ \\
\hline
\end{tabular}

Source: Curtis, 2012, p. 245

The majority of teachers agree that teaching is a moral endeavour (Totterdell, 2000) and that values are central to the daily work of a teacher (Toomey, 2006), but they are perceived as being implicit (Toomey, 2006) and receive far less time and attention in a classroom than subject matter and behavioural issues (Patry, Weyringer, \& Weinberger, 2007). The pre-service teachers in this research study who were not exposed to a values explicit subject remarked that not enough attention was given to values and beliefs in their teacher education programme. Participants who had engaged in the values explicit subject commented on the strengthening of the link between their own values and beliefs and their teaching: "It [FE3] makes you really think about what you're doing, what you're teaching, why you're teaching and how those kids are thinking too" (Study Two Participant 14). This is particularly important given that the process of understanding one's own values and beliefs and how this will impact upon teaching decisions and practices is crucial to quality teaching (Collinson, 1996).

\section{Conclusion}

This research has highlighted the potential for an explicit values-based pedagogy to positively enhance pre-service teachers' competence in quality teaching dimensions. It has contributed to the belief that pedagogy can be transformative (Lovat, Toomey, Clement, Crotty, \& Nielsen, 2009) and that solid values-based practice can have a positive effect on quality teaching - we can prepare pre-service teachers for this. It has demonstrated that a better understanding of and confidence in quality teaching dimensions are achieved by pre-service teachers who are engaged with a values-explicit pedagogy. Preservice teacher understanding within all five quality teaching dimensions was 
enhanced by the addition of a values explicit pedagogy within their teacher education programme, but the improvement in some dimensions was much more marked than others. Changes in the dimension of intellectual quality were perhaps the most marked with the supportive classroom environment dimension also noting positive changes.

Whilst the research has concluded that a values explicit pedagogical focus in pre-service teacher education programmes does enhance pre-service teacher's knowledge of an aptitude in quality teaching, it must be noted that these findings and claims are based on only one example of a values-based pedagogy (Philosophy in the Classroom), and there is no doubt there would be increased benefits to investigating more than one particular pedagogy. Further research could be undertaken into other values-based pedagogies, such as service learning and environmental education, in pre-service teacher education to determine their effect on quality teaching and if they also have the same positive effect on quality teaching as did Philosophy in the Classroom.

By basing teacher education programmes on a values-explicit pedagogy, such as Philosophy in the Classroom, teachers are better prepared in terms of quality teaching dimensions and this in turn positively impacts upon student achievement and student well-being. By engaging pre-service education teachers in the values-explicit pedagogy of Philosophy in the Classroom it allows them the practical experience to implement quality teaching dimensions at the same time as helping them to become "more respectful, tolerant, caring and cooperative people and thus more likely to be quality teachers" (Curtis, 2010 , p. 119). It is only by developing quality teachers that the education of our children can be bettered.

\section{References}

Barber, M., \& Mourshed, D. (2009). Shaping the future: How good education systems can become great in the decade ahead. Report on the International Education Roundtable: 7 July, 2009, Singapore: McKinsey and Company.

Benninga, J. S., Berkowitz, M. W., Kuehn, P., \& Smith, K. (2006). Character and academics: What good schools do. Phi Delta Kappan, 87(6), 448-452.

Birch, S. H., \& Ladd, G. W. (1996). Interpersonal relationships in the school environment and children's early school adjustment: The role of teachers and peers. In J. Juvonen \& K. R. Wentzel (Eds.), Social motivation: Understanding children's school adjustment (pp. 199-225). New York: Cambridge University Press.

Cam, P. (1995). Thinking Together: Philosophical inquiry for the classroom. Alexandria, NSW: Hal \& Iremonger.

Cam, P. (2006). Philosophy and the school curriculum: Some general remarks. Paper presented at the Inaugural Conference on Philosophy in Schools Singapore, April 2006, Singapore.

Carr, D. (2007). Character in teaching. British Journal of Educational Studies, 55(4), 369-389. 
Clement, N. (2007). Perspectives from research and practice in values education. In T. Lovat \& R. Toomey (Eds.), Values education and quality teaching: The double helix effect (pp. 13-27). Terrigal, NSW: David Barlow Publishing.

Cochran-Smith, M., \& Fries, K. (2008). Research on teacher education. In M. Cochran-Smith, S. Feiman-Nemser, D. J. McIntyre \& K. Demers (Eds.), Handbook of Research on Teacher Education (pp. 1050-1093). New York: Routledge.

Collinson, V. (1996). Staff Development through Inquiry: Opening a Pandora's Box of Teacher Beliefs. Paper presented at the Annual Meeting of the Association of Teacher Educators St Louis, St Louis. http://bit.ly/1LhEfn7.

Collinson, V. (1999). Redefining teacher excellence. Theory into Practice, 38(1), 411.

Curtis, E. (2010). Embedding 'philosophy in the classroom' in pre-service teacher education. In R. Toomey, T. Lovat, N. Clement \& K. Dally (Eds.), Teacher education and values pedagogy: A student wellbeing approach (pp. 108-120). Terrigal, NSW: David Barlow Publishing.

Curtis, E. (2012). The heart of quality teaching: A values-based pedagogy for preservice teacher education. (Doctor of Philosophy), Queensland University of Technology, Brisbane.

Daniel, M.-F., \& Auriac, E. (2009). Philosophy, critical thinking and philosophy for children. Educational Philosophy \& Theory, Early View(November 2009).

Davey Chesters, S. (2012). The Socratic Classroom: Reflective thinking through collaborative inquiry. Rotterdam: Sense Publishers.

Davidson, M., Khmelkov, V., \& Lickona, T. (2010). The power of character: Needed for, and developed from, teaching and learning. In R. Toomey, T. Lovat \& N. Clement (Eds.), International research handbook on values education and student wellbeing (pp. 427-454). Dordrecht, Netherlands: Springer.

Dottin, E. S. (2009). Professional judgment and dispositions in teacher education. Teaching and Teacher Education, 25, 83-88.

Eisner, E. (2006). The satisfactions of teaching. Educational Leadership, 63(6), 44-46.

Goldstein, L. S., \& Lake, V. E. (2000). "Love, love, and more love for children": exploring preservice teachers' understandings of caring. Teaching and Teacher Education, 16(8), 861-872.

Hattie, J. (2009). Visible learning: A synthesis of over 800 meta-analyses relating to achievement. London: Routledge.

Hayes, D., Mills, M., Christie, P., \& Lingard, B. (2006). Teachers and Schooling Making A Difference: Productive pedagogies, assessment and performance. Crows Nest, NSW: Allen \& Unwin.

Keeffe, M. (2007). The inclusive society. In M. Keeffe \& S. Carrington (Eds.), Schools and diversity (2nd ed., pp. 17-30). Frenchs Forest, NSW: Pearson Education Australia.

Landorf, H., Rocco, T. S., \& Nevin, A. (2007). Creating permeable boundaries: teaching and learning for social justice in a global society. Teacher Education Quarterly, 34(1), 41-56.

Lipman, M. (2003). Thinking in Education (2nd ed.). New York: Cambridge University Press.

Lipman, M., Sharp, A. M., \& Oscanyan, F. (1980). Philosophy in the Classroom (2nd ed.). Philadelphia: Temple University Press.

Lovat, T. (2007). Synergies and balance between values education and quality teaching. Paper presented at the Moral Education and Australian Values Conference, Monash University, Melbourne. http://bit.ly/1f2sNQ0 
Lovat, T., \& Clement, N. (2008). Quality teaching and values education: coalescing for effective learning. Journal of Moral Education, 37(1), 1 - 16.

Lovat, T., Dally, K., Clement, N., \& Toomey, R. (2011). Values pedagogy and student achievement: Contemporary research evidence. Dordrecht: Springer.

Lovat, T., \& Toomey, R. (2007a). The 'double helix' relationship between quality teaching and values education: Emerging issues for teacher educators. Canberra: Australian Council of Deans Incorporated.

Lovat, T., \& Toomey, R. (2007b). Values education: A brief history to today. In T. Lovat \& R. Toomey (Eds.), Values education and quality teaching: The double helix effect (pp. xi-xix). Terrigal, NSW: David Barlow Publishing.

Lovat, T., Toomey, R., Clement, N., Crotty, R., \& Nielsen, T. W. (2009). Values Education, Quality Teaching and Service Learning: A troika for effective teaching and teacher education. Terrigal, NSW: David Barlow Publishing.

McCall, C. C. (2009). Transforming thinking: Philosophical inquiry in the primary and secondary classroom. Abingdon: Routledge.

Narvaez, D. (2010). Building a sustaining classroom climate for purposeful ethical citizenship. In T. Lovat, R. Toomey \& N. Clement (Eds.), International research handbook on values education and student wellbeing (pp. 659-673). Dordrecht: Springer.

Noddings, N. (2001). The caring teacher. In V. Richardson (Ed.), Handbook of research on teaching (4th ed., pp. 99-105). Washington: American Educational Research Association.

Noddings, N. (2005). The challenge to care in schools: An alternative approach to education (2nd ed.). New York: Teachers College Press.

Osguthorpe, R. D. (2008). On the reasons we want teachers of good disposition and moral character. Journal of Teacher Education, 59(4), 288-299.

Osterman, K. F. (2010). Teacher practice and students' sense of belonging. In T. Lovat, R. Toomey \& N. Clement (Eds.), International research handbook on values education and student wellbeing (pp. 239-260). Dordrecht, Netherlands: Springer.

Patry, J.-1., Weyringer, S., \& Weinberger, A. (2007). Combining values and knowledge education. In Aspin \& Chapman (Eds.), Values education adn lifelong learning: Principles, policies, programmes (pp. 160-179). The Netherlands: Springer.

Paul, R. W. (1993). Critical thinking: How to prepare students for a rapidly changing world. Santa Rosa, CA: Foundation for Critical Thinking.

Pianta, R. C., \& Stuhlman, M. W. (2004). Teacher-child relationships and children's success in the first years of school. School Psychology Review, 33(3), 444-458.

Slee, R. (2007). Inclusive education - aspirations scrambled by the yoke of history? In M. Keeffe \& S. Carrington (Eds.), Schools and diversity (2nd ed., pp. 1-16). Frenchs Forest, NSW: Pearson Edcuation Australia.

Sokol, B., Hammond, S., \& Berkowitz, M. W. (2010). The developmental contours of character. In T. Lovat, R. Toomey \& N. Clement (Eds.), International research handbook on values education and student wellbeing (pp. 579-604). Dordrecht, Netherlands: Springer.

Splitter, L., \& Sharp, A. M. (1995). Teaching for better thinking: The classroom community of inquiry. Melbourne: The Australian Council for Educational Research. 
Tan, S., \& Leong, T. C. (2006). The place of philosophy in affective education. Paper presented at the Inaugural Conference on Philosophy in Schools Singapore, April 2006, Singapore.

The University of Queensland. (2001). The Queensland School Reform Longitudinal Study. Brisbane: The State of Queensland (Department of Education).

Toomey, R. (2006). Values as the centrepiece of the school's work: A discussion paper on learnings from VEGPSP Stage 1. Canberra: Curriculum Corporation.

Toomey, R. (2007). The double helix and its implications for the professional lifelong learning of teachers. In T. Lovat \& R. Toomey (Eds.), Values Education and Quality Teaching: The double helix effect (pp. 157-166). Terrigal, NSW: David Barlow Publishing.

Topping, K. J., \& Trickey, S. (2007). Impact of philosophical enquiry on school students' interactive behaviour. Thinking Skills and Creativity, 2(2), 73-84.

Totterdell, M. (2000). The moralization of teaching: A relational approach as an ethical framework in the professional preparation and formation of teachers. In R. Gardner, J. Cairns \& D. Lawton (Eds.), Education for Values: Morals, ethics and citizenship in contemporary teaching (pp. 127-146). London: Kogan Page Limited.

UNESCO. (1994). The Salamanca Statement and Framework for Action on Special Needs Education: UNESCO. 